\title{
Effect of increasing Helicobacter pylori ammonia production by urea infusion on plasma gastrin
} concentrations

\author{
R S Chittajallu, W D Neithercut, A M I Macdonald, K E L McColl
}

\begin{abstract}
It has been proposed that the hypergastrinaemia in subjects with Helicobacter pylori infection is caused by the action of the ammonia produced by the organism's urease activity on the antral $G$ cells. To investigate this hypothesis we examined the effect on plasma gastrin of increasing the bacterium's ammonia production by infusing urea intragastrically to eight $H$ pylori positive duodenal ulcer patients. After a 60 minute control intragastric infusion of dextrose solution at $2 \mathrm{ml} /$ minute, a similar infusion containing urea (50 mmol/l) was continued for four hours. During the urea infusion, the median gastric juice urea concentration rose from $1.1 \mathrm{mmol} / 1$ (range 0.3-1.6) to $15.5 \mathrm{mmol} / \mathrm{l}$ (range 7.9-21.3) and this resulted in an increase in the ammonium concentration from $2.3 \mathrm{mmol} / \mathrm{l}$ (range 1.3-5.9) to $6 \cdot 1 \mathrm{mmol} / \mathrm{l}$ (range 4.2-11.9) $(\mathbf{p}<0.01)$. This appreciable rise in ammonia production did not result in any change in the plasma gastrin concentration. The experiment was repeated one month after eradication of $H$ pylori, at which time the median basal gastrin was $20 \mathrm{ng} / \mathrm{l}$ (range 15-25), significantly less than the value before eradication $(30 \mathrm{ng} / 1$ range $15-60)(p<0 \cdot 05)$. On this occasion, the gastric juice ammonium concentration was considerably reduced at $0.4 \mathrm{mmol} / \mathrm{l}$ (range $0 \cdot 1-0.9)$ and the urea infusion did not raise the ammonium concentration or change the plasma gastrin concentration. In conclusion, augmenting $\boldsymbol{H}$ pylori ammonia production does not cause any early change in plasma gastrin.
\end{abstract}

More than $95 \%$ of patients with duodenal ulcer disease have chronic Helicobacter pylori (formerly Campylobacter pylori) infection of the gastric antrum, ' and eradication of this reduces the ulcer relapse rate. ${ }^{2}$ It has recently been shown that patients with the infection have raised plasma gastrin concentrations ${ }^{3}$ which fall when the infection has been cleared. ${ }^{45}$ Because this increase in the plasma gastrin concentration is associated with raised intragastric acidity after meals, ${ }^{4}$ gastrin may be the link between chronic $H$ pylori infection and duodenal ulceration. ${ }^{3}$ The mechanism by which $H$ pylori infection increases the plasma gastrin concentration is unknown but could be related to its high urease enzyme activity, which results in high intragastric ammonium ion concentrations in gastric juice. ${ }^{6}$ The bacterium is mainly found under the gastric mucus layer close to the antral epithelial cells and its formation of ammonia may raise the $\mathrm{pH}$ of the epithelial surface. Because the release of gastrin by antral $G$ cells is normally suppressed by intragastric acid, ${ }^{7}$ a rise in mucosal $\mathrm{pH}$ due to high concentrations of ammonia could explain the increased gastrin release. There is also evidence from animals that ammonium uptake by $G$ cells is a mechanism by which gastrin release is mediated. ${ }^{8}$

To determine whether the raised plasma gastrin concentraton is the result of ammonia production by $H$ pylor $i$ we have studied the effect of altering the rate of ammonia formation on plasma gastrin concentration by infusing urea intragastrically.

\section{Patients}

Eight patients (five men) with a history of endoscopically confirmed duodenal ulceration within the previous year were studied. Their ages ranged from 26 to 62 years. Each of the patients had $H$ pylori infection of the gastric antrum confirmed by histology of antral biopsy specimens, rapid urease test (CLO test), ${ }^{9}$ and 14C urea breath test. ${ }^{10}$ None had taken any acid inhibitory agents or bismuth preparations in the month before the study.

\section{Methods}

The plasma gastrin response to increasing $H$ pylori ammonia production was investigated by infusing a urea solution into the gastric antrum. Each patient acted as his or her own control by having the urea infusion repeated one month after a three week course of tripotassium dicitratobismuthate (De-Noltab) $120 \mathrm{mg}$ qid, and metronidazole $400 \mathrm{mg}$ tid designed to eradicate $H$ pylori. Confirmation of eradication of $H$ pylori was achieved by repeating the endoscopic antral biopsies and 14C urea breath test one month after the completion of treatment.

After a 16 hour overnight fast a dual lumen size $16 \mathrm{~F}$ gastric tube, which has multiple ports over its distal $6 \mathrm{~cm}$ (Andersen Inc, New York), was passed nasogastrically and positioned radiographically so that its tip lay in the distal part of the stomach. An intravenous cannula was inserted into the antecubital vein. At the end of a 30 minute basal period the stomach was emptied, and over the following hour dextrose solution (328 $\mathrm{mmol} / \mathrm{l}$ ) that did not contain urea was infused into the stomach at a rate of $2 \mathrm{ml}$ per minute. After this control period, a dextrose solution containing urea $(50 \mathrm{mmol} / \mathrm{l})$ was infused at a rate of $2 \mathrm{ml}$ per minute for four hours. The concentration of dextrose in the urea solution was reduced by $50 \mathrm{mmol} / 1$ so that the osmolalities of the two infusions were the same. In addition, the $\mathrm{pH}$ of the solutions was reduced to 1.8 by 
adding $1 \mathrm{ml}$ concentrated HCL per $500 \mathrm{ml}$ dextrose to prevent them raising intragastric $\mathrm{pH}$.

Venous blood samples were obtained at 30 minute intervals throughout the experiment for plasma gastrin determination and were collected in lithium heparin tubes containing $4000 \mathrm{KIU}$ aprotinin (Trasylol). The blood was centrifuged at $3000 \mathrm{~g}$ for 10 minutes at $4^{\circ} \mathrm{C}$ and the plasma was stored at $-20^{\circ} \mathrm{C}$. During the intragastric infusions, $10 \mathrm{ml}$ samples of gastric juice were collected every 15 minutes for measurement of the ammonium and urea concentration and determination of $\mathrm{pH}$. At the end of each hour all the gastric contents were aspirated to prevent the accumulation of infusate.

The plasma gastrin concentration was measured by radioimmunoassay using antibody R98 which has a lower limit of detection of 5-10 ng/l." Gastric aspirate urea concentrations were measured by a urease method (SMAC I Technicon, Basingstoke, UK) and ammonium concentrations by an enzymatic method (SIGMA, Dorset, UK). The $\mathrm{pH}$ of the gastric aspirate was measured with a glass electrode (Radiometer ETS 822).

Statistical significance was assessed by the Wilcoxon signed rank sum test. The study was approved by the Western Infirmary Ethical Committee and each patient gave informed written consent.

\section{Results}

In seven patients the $H$ pylori infection was successfully eradicated as confirmed by the absence of organisms and resolution of gastritis seen on antral biopsy specimens, negative CLO test, and negative $14 \mathrm{C}$ urea breath test four weeks after completing the antibacterial treatment. Their median 20 minute breath test value was $135 \%$ of administered dose per mmol $\mathrm{CO}_{2} \times \mathrm{kg}$ body weight $\times 100$ (range 104-251) before treatment and fell to $4 \cdot 5$ (range $0 \cdot 6-7$ ) one month afterwards. The one patient in whom the organism was not cleared was excluded from further analysis.

\section{BASAL VALUES}

The median concentration of ammonium ions in the basal gastric aspirate before eradication of $H$ pylori was $4.4 \mathrm{mmol} / \mathrm{l}$ (range $1 \cdot 8-14 \cdot 7$ ) and this fell after eradication to $0.7 \mathrm{mmol} / \mathrm{l}$ (range $0.3-1.4)(\mathrm{p}<0.02)$ (Fig 1). The median concentration of urea in the basal gastric aspirate was $1.1 \mathrm{mmol} / 1$ (range $0 \cdot 3-1 \cdot 6$ ) and rose to $2.5 \mathrm{mmol} / \mathrm{l}$ (range $1.0-3.4$ ) after eradication $(p<0.02)$. The median plasma concentration of gastrin was $30 \mathrm{ng} / \mathrm{l}$ (range 15-60) and this fell to $20 \mathrm{ng} / \mathrm{l}$ (range 15-25) $(\mathrm{p}<0.05)$ after eradication. The median $\mathrm{pH}$ of the basal gastric aspirates did not change significantly - it was $\mathrm{pH} 1.7$ (range $1 \cdot 2-1 \cdot 9)$ before and 1.6 (range $1 \cdot 2-1 \cdot 7$ ) after eradication of $H$ pylori.

EFFECT OF INTRAGASTRIC INFUSIONS

During the 60 minute control infusion of dextrose solution, both before and after eradication, there was a progressive fall in urea and
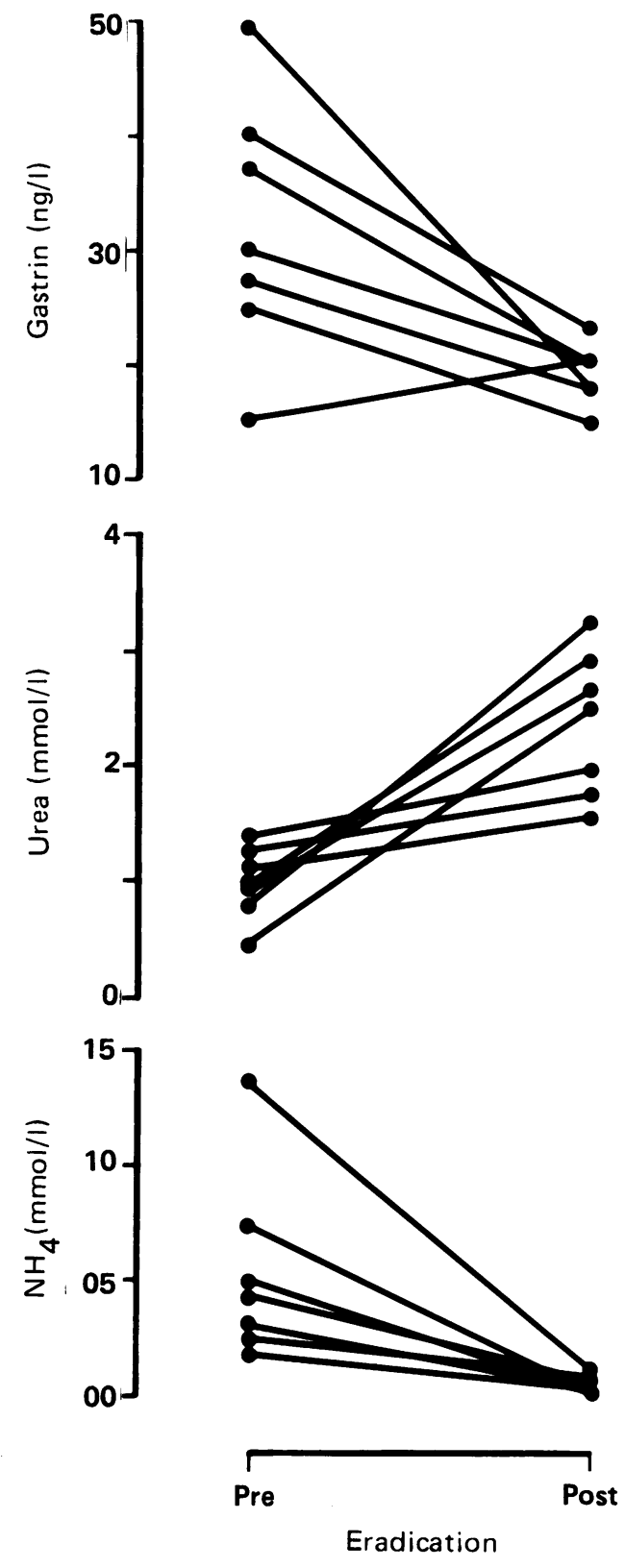

Figure 1: Gastric juice concentrations of urea and ammonia and plasma gastrin concentrations before and after eradication of Helicobacter pylori infection in 7 duodenal ulcer subjects. After eradication plasma gastrin concentration and gastric juice ammonium concentration were lower $(p<0.05, p<0.02$ respectively) and the gastric juice urea concentration increased $(p<0.02)$.

ammonium concentrations in the gastric aspirate due to dilution by the infusate (Figs 2 and 3 ). Plasma gastrin concentration did not change over this period.

Before eradication of $H$ pylori, the urea infusion resulted in a rise in the gastric aspirate urea concentrations which reached a plateau after 60 minutes at a median value of $15.5 \mathrm{mmol} / \mathrm{l}$ (range 7.9-21.3) (Fig 2). The median gastric juice ammonium concentration immediately before beginning the urea infusions was $2 \cdot 3 \mathrm{mmol} / 1$ (range $1 \cdot 3-5 \cdot 9$ ) and rose over 90 minutes to reach a median plateau value of $6 \cdot 1 \mathrm{mmol} / \mathrm{l}$ (range $4 \cdot 2-11 \cdot 9$ ). This rise in ammonium production was not accompanied by any change in plasma gastrin concentration (Fig 2).

After eradication of $H$ pylori, the rise in gastric juice urea concentration during urea infusion 
Figure 2: Effect of intragastric infusion of urea on gastric juice concentrations of urea and ammonium, intragastric $\mathrm{pH}$ and plasma gastrin concentration in 8 patients with Helicobacter pylor infection of the gastric antrum. (Values are medians.)

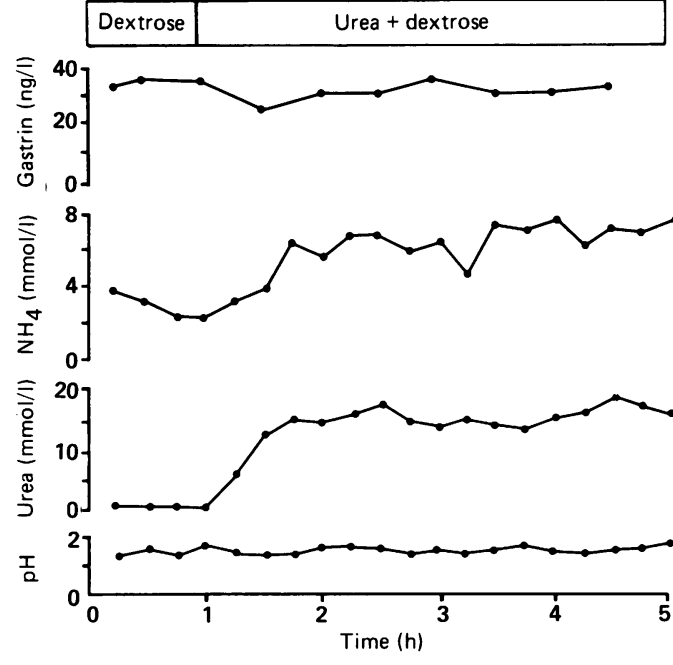

was similar to that before eradication (Fig 3). On this occasion, however, there was no rise in the ammonium concentration. The median value immediately before beginning the infusion was $0.4 \mathrm{mmol} / \mathrm{l}$ (range $0 \cdot 1-0.9$ ) and it was $0.4 \mathrm{mmol} / \mathrm{l}$ (range $0.3-1 \cdot 2$ ) at the end of the infusion. The median gastrin concentration, which was lower after eradication of $H$ pylori, was unaffected by the urea infusion.

The $\mathrm{pH}$ of gastric aspirates remained between 1.5 and 2.0 throughout the studies.

\section{Discussion}

In agreement with previous work, ${ }^{4}$ this study has shown that there is a considerable lowering of plasma gastrin concentrations after eradication of $H$ pylori infection in duodenal ulcer subjects. The finding that increasing $H$ pylori ammonia production failed to change the plasma gastrin concentration does not lend support to the hypothesis that the hypergastrinaemia is caused by the ammonia. It seems unlikely that the degree of increase in ammonia production was inadequate as the rise in the ammonium ion concentration at the antral epithelial surface, where the bacteria are found close to the gastrin secreting G cells, would have been even greater than the three fold rise noted in the gastric aspirate. It should be stressed, however, that the failure to cause a further increase in gastrin by augmenting ammonia production does not

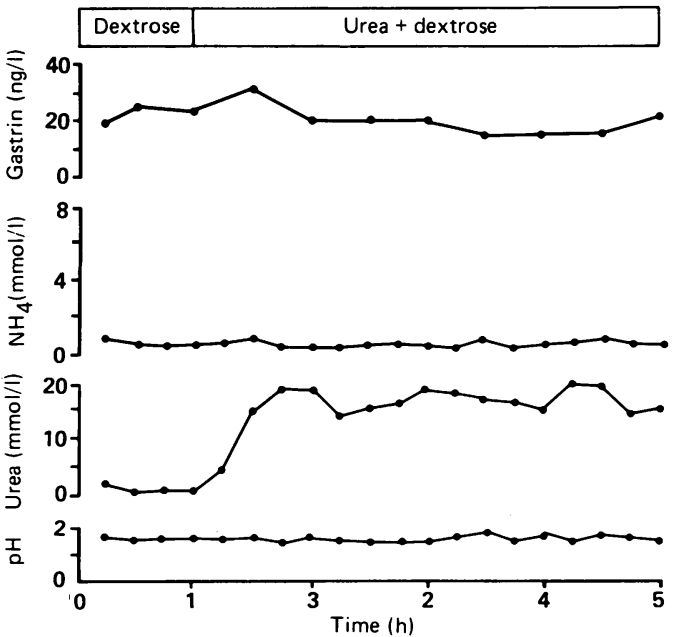

exclude the possibility that the raised gastrin value was caused by the organism's ammonia production. The amount of ammonia produced by the bacterium under normal conditions may be sufficient to produce the maximum gastrin response via this mechanism.

It has been proposed by Levi et al that the increased plasma gastrin concentrations are caused by the organism's ammonia production raising antral surface $\mathrm{pH} .{ }^{3}$ This would interfere with the physiological suppression of gastrin release by luminal acid. Our finding that augmenting $H$ pylori ammonia production fails to stimulate gastrin release does not refute this hypothesis. The local alkalinising effect of $H$ pylori under basal conditions may already be sufficient to prevent suppression of gastrin release by gastric acid. In addition, the duration of the urea infusion in our study was four hours and earlier studies have shown that gastric alkalinisation was required for five hours before there was any rise in serum gastrin. '2 The effect of antral alkalinisation on serum gastrin in humans is controversial, however, as a more recent study could not detect any increase after raising gastric $\mathrm{pH}$ for 10 hours. ${ }^{13}$ Unfortunately, there are no studies of the effect of gastric alkalinisation on serum gastrin in patients of known $H$ pylori status.

Other mechanisms by which $H$ pylori infection of the gastric antrum may be stimulating excessive gastrin release need to be considered also. Eradication of the infection results in resolution of the antral gastritis and it is possible that it is the inflammatory cell infiltrate in the region of the $\mathrm{G}$ cells that is responsible for the hypergastrinaemia. A recent study has indicated that the hypergastrinaemia correlates better with antral gastritis than with $H$ pylori infection. ${ }^{1+}$ As the gastritis associated with the bacterial infection may be at least partly caused by the damaging effects of the ammonia, ${ }^{15}$ it may be very difficult in practice to differentiate the effects of the two.

This study also provides information on the regulation of $H$ pylori ammonia production in vivo. The almost undetectable intragastric concentrations of urea found before eradication of the organism and the rapid rise in gastric ammonia concentration after the infusion of urea indicate that the gastric juice concentration of urea and its rate of diffusion across the gastric mucosa are factors that limit the generation of ammonia by $H$ pylori. It has been proposed that the organism's ammonia production is a means by which it protects itself from intragastric acid by producing a local alkaline microenvironment. ${ }^{16}$ As gastric $\mathrm{pH}$ varies constantly and rapidly, such a protective mechanism should be under $\mathrm{pH}$ dependant control rather than under the control of substrate availability, which cannot be altered. The main function of the enzyme is more likely to be to scavenge nitrogen from urea for use in the synthesis of amino acids and nucleic acids.

In conclusion, though lowering intragastric ammonia concentration by eradicating $H$ pylori is accompanied by a lowering of the plasma gastrin concentration, augmenting the bacterium's ammonia production is not accompanied by a further increase in plasma gastrin. The intragastric infusion of urea on gastric juice concentrations of urea and ammonium, intragastric $p H$, and plasma gastrin concentration in 7 patients after eradication of Helicobacter pylori infection. (Values are medians.) 
mechanism by which $H$ pylori raises plasma gastrin concentrations, therefore, remains unclear.

This work was supported by a grant from the Biomedial Research Council of the Scottish Home and Health Department.

1 Marshall BJ, McGechie DB, Rogers PA, Glancy RG. Pyloric campylobacter infection and gastroduodenal disease. Med $\mathcal{F}$ Aust 1985; 142: 439-44.

2 Marshall BJ, Goodwin CS, Warren JR, et al. Prospective double blind trial of duodenal ulcer relapse after eradication of campylobacter pulori. Lancet 1988; ii: 1437-42.

3 Levi S, Haddad G, Ghosh P, Beardshall K, Playford R, Calam J. Campylobacter pylor and duodenal ulcers; the gastrin link. Lancet 1989; i: 1167-8.

4 McColl KEL, Fullarton GM, Nujumi AM El, Macdonald AM, Brown IL, Hilditch TE. Lowered gastrin and gastric AM, Brown IL, Hilditch TE. Lowered gastrin and gastric acidity after eradication of Campy

5 Oderda G, Holton J, Altare F, Vaira D, Ainley C, Ansaldi N. Amoxycillin plus tinidazole for Campylobacter pylori gastriti in children: assessment by serum IgG antibody, Pepsinogen and gastrin levels. Lancet 1989; i: 690-2.

6 Marshall BJ, Langton SR. Urea hydrolysis in patients with Campylobacter pyloridis infection. Lancet 1986; i: $965-6$.
7 Oberhelman HA, Woodward ER, Zubiran JM, Dragstedt LR. Physiology of the gastric antrum. Am $\mathcal{F}$ Physiol $1952 ; 169$. 738-48.

8 Lichtenberger LM, Graziani LA. Possible importance of dietary ammonia in the postprandial release of gastrin $(\mathrm{G})$. Gastroenterology 1981;80: 1212 .

9 Marshall BJ, Warren JR, Francis GJ, Langton S, Goodwin CS, Blincolm ED. Rapid urease test in the management of Campylobacter pyloridis associated gastritis. Am $\mathcal{J}$ GastroCampylobacter pyloridis as

10 Bell GD, Weil J, Harrison G, et al. 14 C urea breath test analysis, a non invasive test for Campylobacter pylori in the stomach. Lancet 1987 i: 1367-8

11 Ardill JES. The measurement of gastrin by radio-immunoassay. [PhD Thesis.] Belfast: Queens University, 1973.

12 Peters MN, Feldman M, Walsh JH, Richardson CT. Effect of gastric alkalinisation on serum gastrin concentration in humans. Gastroenterology 1983; 85: 35-9.

13 Peterson WL, Walsh JH, Richardson CT. Cimetidine blocks antacid-induced hypergastrinaemia Gastroenterology ' 1986; 90: 48-52.

14 Wyatt JI, Rathbone BJ, Green DM, Primrose J. Raised fasting serum gastrin in chronic gastritis is independent of Campslobacter pylori status and duodenal ulceration. [Abstract]. lobacter pylori status
Gut 1989; 30: A1483

15 Yoshida H, Imoto I, Shida Y, Suzuki S. The significance of Campylobacter pylori infection on the development of gastric mucosal injury - urease - protease theory. [Abstract] Gastroenterology 1989; 96: A562.

16 Goodwin CS, Armstrong JA, Marshall BJ. Campylobacter pyloridis, gastritis and peptic ulceration. $\mathcal{F}$ Clin Pathol 1986 39: 353-65. 